\section{The mediating effect of transparency in the relationship between corporate social responsibility and corporate reputation}

\section{Elisa Baraibar-Diez}

University of Cantabria, Department of Business Administration, Santander, Spain

\section{Ladislao Luna Sotorrío}

University of Cantabria, Department of Business Administration, Santander, Spain

\section{Received on}

11/22/2016

Approved on

08/29/2017

Responsible editor:

Prof. Dr. Joao Mauricio Boaventura

\section{Evaluation process:}

Double Blind Review

\begin{abstract}
Purpose - This study attempts to shed light on the relationship between the implementation of corporate social responsibility (CSR) actions and the creation of corporate reputation. We go further and wonder which is the role of transparency - a step beyond disclosure - in that relationship.
\end{abstract}

Design/methodology/approach - A structural equations model using the statistical package lavaan in $\mathrm{R}$ is applied to 22 Spanish listed companies during the period 2002-2015.

Findings - The proposed model shows that transparency mediates the path between corporate social responsibility and corporate reputation.

Originality/value - This paper highlights the importance of transparency beyond disclosure since information aims to meet certain criteria such as relevance, understandability and timeliness. A new measurement for transparency analyzed its mediating effect in the relationship between corporate social responsibility and corporate reputation.

Keywords - Transparency; mediating effect; corporate social responsibility; corporate reputation 


\section{Introduction}

The importance of corporate social responsibility (CSR) stems from the interest of the firm to integrate social issues in order to ensure sustainable development. This process is based on the belief that implementing CSR actions provides a better assessment of the activity and thereby an improvement of corporate performance in the long term (de la Fuente \& de Quevedo, 2003; Devine \& Halpern, 2001). Companies spend more and more resources on social issues and to be effective, CSR information must be conveyed to stakeholders. Thus, companies face a challenge not only when trying to meet stakeholders' expectations regarding the product, the service or even corporate behavior, but also in a matter of information (Odriozola \& Baraibar-Diez, 2017). In fact, the significant increase of information disclosed by the company and its impact on investor confidence (Holt \& DeZoort, 2009; Wilson \& Walsh, 1996) contribute to highlight the need for further research in this area, where concepts such as CSR disclosure or CSR reporting have emerged and begin to be valued as an essential part of the CSR strategy (Dubbink, Graafland, \& Van Liedekerke, 2008; Prado-Lorenzo, GarciaSanchez, \& Gallego-Álvarez, 2012).

Disclosure and reporting of information are inevitably linked to transparency (Dubbink et al., 2008; Fuente, García-Sánchez, \& Lozano, 2017), as long as the company makes information available and accessible. The main point of attention when studying transparency is the unanimity of researchers, institutions, regulators and agents of opinion on what important and desirable transparency is for the efficient development of economic activity (Baraibar-Diez, Odriozola, \& Fernández, 2017). The problem lies in how to adjust transparency with disclosure and reporting and, especially, in how to apply transparency in practice, in terms of information content, quality of information or the most effective way or channel to reach stakeholders.
These issues are important and complex, which explains the slow progress of research in this area.

Although literature shows many studies that analyze the relationships between CSR (including CSR disclosure and CSR reporting) and the outcomes in terms of (financial/social) performance and even corporate reputation (Brammer \& Pavelin, 2006, 2016; Cochran \& Wood, 1984; Falkenberg \& Brunsael, 2011; Story \& Neves, 2014), the truth is that, so far, transparency has not been considered as a mediator in the relationship between CSR actions and corporate reputation. This study focuses on the relationship between CSR and corporate reputation and contributes to the current literature by highlighting that the company will achieve higher reputation by implementing CSR actions when transparency beyond disclosure is included and examined. Delving into this relationship is motivated by the benefits that greater reputation may have for a company (Zavyalova, Pfarrer, Reger, \& Hubbard, 2016), for example financial value (Schnietz \& Epstein, 2005), employee recruitment and retention benefits (Hogarth, Hutchinson, \& Scaife, 2016), customer interest (Hogarth et al., 2016) or status (George, Dahlander, Graffin, \& Sim, 2016).

This study is important insofar as certain requirements of the information disclosed make a difference when trying to effectively reach stakeholders (Odriozola \& Baraibar-Diez, 2017; Pérez, López, \& García-De los Salmones, 2017). Following the line of studies related to disclosure of CSR information and the issuance of CSR reports and its effect on corporate reputation (Pérez et al., 2017), this contribution takes a step further from the mere disclosure of information and focuses on "how" that information is disclosed. In fact, it aims to test whether how disclosed information mediates the proven relationship between CSR and corporate reputation. To achieve this goal, a structural equation model, using the statistical package lavaan in $\mathrm{R}$, was applied to 22 Spanish listed companies during the period 2002-2015. 


\section{Literature review}

\section{I CSR, transparency and corporate reputation}

The point of departure to theoretically analyze the effect of transparency on the effectiveness of CSR in achieving reputation is the recognition of the interest of the company in taking social actions beyond the economic activity and strict compliance with the law, contrary to the proposals of the classical theory (Friedman, 1970; Jensen \& Meckling, 1976), which considered social actions as ineffective. This classical theory, identified within the group of instrumental theories expounded by Garriga and Melé (2004), prioritizes the economic feature in the interaction between business and society and accepts social actions as long as they entail an economic return.

Additionally, the theoretical justification for the adoption by the company of social, labor and environmental actions which are grouped around its CSR (see Dahlsrud, 2008 for an analysis of definitions of CSR) can be made from a normative approach, which considers those actions as ethically necessary regardless of their economic impact - perspectives grouped around the theory of legitimacy -, or from a positive approach, which considers those actions as having positive economic effects for the company, such as the case with agency theory or the theory of stakeholders.

The stakeholder theory has become the dominant paradigm when contextualizing CSR integrating normative aspects of the legitimacy theory and positive aspects of the agency theory (Garriga \& Melé, 2004), including the interests and demands of other stakeholders in addition to shareholders (Mitchell, Agle, \& Wood, 1997). Therefore, stakeholder theory provides a more inclusive vision as it tries to favor the interests of all groups involved in the company (Odriozola \& Baraibar-Diez, 2017). In this sense, CSR is considered as "the corporate attempt to negotiate its relationship to stakeholders and the public at large" (Ihlen, Bartlett, \& May, 2011, p. 8), which enhances legitimization of corporate actions.
In addition, disclosure of CSR information, implicit in the concept of transparency (Aksu \& Kosedag, 2006), is considered as "a management tool to negotiate informative needs of several groups of stakeholders with a power in the firm (employees, shareholders, investors, consumers, public authorities and NGOs)" (Reverte, 2009, p. 353). This work is placed within the theory of stakeholders, which is widely employed as a framework to understand CSR, CSR disclosure, and CSR reporting and its relationship with reputation (Odriozola \& Baraibar-Diez, 2017; Pérez et al., 2017).

Corporate reputation is commonly understood as the perception of every stakeholder that their expectations have or have not been met by the firm (de Quevedo-Puente, de la Fuente, \& Delgado, 2005; Walker, 2010) and the only way that stakeholders can assess whether this has occurred is through the information disclosed by the company. In this sense, disclosure of information affects the perception of stakeholders about how the company, significantly influences the reputation of the firm and is a key element to safeguard the identity of the corporation (Hooghiemstra, 2000). This is not the only benefit of corporate reputation, as this stock variable (Zavyalova et al., 2016) is the result of trustworthy behavior (Hosmer, 1995) and provides other benefits such as financial value (Schnietz \& Epstein, 2005), positive effects on human resources or consumer interest (Hogarth et al., 2016) and generates status (George et al., 2016), which encourages companies to improve the way of achieving corporate reputation.

Of all the previously presented concepts related to CSR and its effects, the potential specific link between CSR and corporate reputation has received less empirical research. In fact, the database Web of Science reports only 35 studies on both concepts (corporate social responsibility and reputation) in the title together from 2010 to 2017, with effects in both directions. There are studies that find that prior corporate reputation has an impact on how consumers evaluate CSR 
activities (Lee, Chang, Kim, \& Lee, 2016; Skard \& Thorbjornsen, 2014) but the major stream refers to the effect of CSR on corporate reputation (Brammer \& Pavelin, 2004; Eberle, Berens, \& Li, 2013; Fernández Sánchez, Luna Sotorrio, \& Baraibar Diez, 2015; Fombrun \& Shanley, 1990; Kim, 2015; Luna \& Baraibar, 2011; Melo \& Garrido-Morgado, 2012; Odriozola, Martín, \& Luna, 2015; Toms, 2002). That is why it is considered as a circular relationship (Olmedo, Martínez, Arcas, \& Longuinos, 2012), although there are also studies from other points of view, considering reputation as a mediator between CSR and brand performance (Lai, Chiu, Yang, \& Pai, 2010), financial performance (Saeidi, Sofian, Saeidi, Saeidi, \& Saaeidi, 2015), or multiple stakeholder outcomes (Arikan, Kantur, Maden, \& Telci, 2016).

The major stream confirms empirically that there is a significant and direct relationship between CSR and reputation but the underlying question is which role transparency plays in this relationship. Although there are authors including variables affecting that relationship (Fernández Sánchez et al., 2015), none of them have analyzed the role of transparency before.

\subsection{Transparency and its characteristics}

Disclosure of information is considered the means to manage the informative needs of several types of stakeholders, structuring social actions as a way to make the business more profitable, incorporating ethical, social and environmental values in the decision-making process (Piechocki, 2004; Toms, 2002). Undeniably, the origin of the concept of transparency is the disclosure of corporate information as a means of reducing information asymmetry between the company and its stakeholders in order to reduce transactional costs and improve efficiency, but the problem arises when the concept of disclosure is identified with transparency.

Disclosure of information traditionally confronted the preference for secrecy (Gray, 1988) of the directors, who were in favor of confidentiality and restriction of information to those intimately involved in management and financing. The tendency to increase the amount of information disclosed by the firm as part of an open style initially led to the frequent use of the term transparency until Bushman, Piotroski, and Smith (2004) introduced the term corporate transparency as 'the availability of firm-specific information to those who are outside', a term that remains in the works, among others, of Kaptein and Van Tulder (2003), Almazán, Suárez and Titman (2003), or Aggarwal and Kyaw (2009).

The first question that arises when defining transparency is to determine the amount and type of information disclosed. In this sense, it seems clear that, traditionally, financial information has been the most relevant as it has been the first to become standardized and mandatory in many countries. Although in recent years it is receiving more attention (Campbell, Craven, \& Shrives, 2003; Dierkes \& Antal, 1985), research analyzing the effect of social transparency related to nonfinancial and non-regulated features (ESG environmental, social, governance - information) is less numerous, more heterogeneous and less conclusive. Whereas financial information should be understandable only to those with reasonable knowledge of business and economic activities (Ewer, 2007), ESG information should reach groups with different training, different claims and using different media, forcing the company to make greater efforts to try to adapt the information. Thus, transparency really goes beyond information disclosed and includes all legal, policy and institutional structures that generates information and the channel by which it is distributed (Finel \& Lord, 1999), with special emphasis on accessibility, frequency and reliability of information (Armstrong, 2005).

The complexity of the concept of transparency stems not only from the need to identify the aspects of the firm that are relevant to a heterogeneous group of stakeholders but also from the form, channel and timing of disclosure to be effectively relevant. Thus, corporate social 
transparency could be defined as the availability of relevant, understandable and timely social (or ESG) information by the firm in order to allow stakeholders to make rational decisions and contribute to the company's sustainable development (Baraibar-Diez \& Luna-Sotorrio, 2012):

Relevance of information. The interaction between the firm and its stakeholders allows the identification of their expectations or demands for information (Piechocki, 2004). The company that aspires to be transparent must disclose information to respond to those expectations by ensuring the transmission of new, crucial and accurate information, regardless of the nature of the information, that is, positive or negative events (Fung, Weil, Graham, \& Fagotto, 2004; Ortiz Martínez \& Crowther, 2008). Relevance of information disclosed has a quantitative part, since economic agents that receive information believe that social information is not sufficient to make a reliable assessment of the company (García-Meca \& Martínez 2005), and a qualitative part provided by the standardization through the development of social information according to recognized standards or by the certification and assurance of disclosed information (Odriozola \& Baraibar-Diez, 2017).

Understandability of information. This comes from the appropriateness of the message, the channel of communication and the characteristics of its receivers. Due to heterogeneity of stakeholders (employees, government, NGOs, suppliers, customers, consumers, society at large, etc.), the firm should suit the information disclosed to the ability of every stakeholder to understand it. A way to facilitate this understanding is by generating quantifying indicators (Botosan, 1997) that allow the assessment of the current situation of the firm and its evolution.

Timeliness of information. Failure to provide information at a time, place or format available to stakeholders (Fung et al., 2004) makes the previously described characteristics of relevance and understandability less important, which turns timeliness into a key issue for social and financial information (Jensen, Marshall, \& Pugh, 2006). Measurement of timeliness is one of the most challenging issues for researchers, who have focused on frequency or information in good time when trying to measure it (Penno, 1997).

\section{Model and hypotheses development}

Mediation occurs when an independent variable affects an outcome variable through a third variable, called mediator (Baron \& Kenny, 1986). The concept of transparency takes part in many mediating relationships, especially in the field of human resources (Sharma, 2009; Vogelgesang, Leroy, \& Avolio, 2013) or trust in government (Song \& Lee, 2015). Several authors, such as Surroca, Tribo, \& Waddock, (2010), Huang and Lien (2012) or Blanco, GuillamónSaorín, and Guiral, (2013), have previously raised the inclusion of mediating effect explanations in the relationship between social and financial performance. However, previous studies have focused on the role of innovation. We intend to extend and improve the understanding of the link between CSR and reputation by implementing a mediation analysis with SEM, which is the preferred method (Frazier, Tix, \& Barron, 2004) to test mediation.

Taking into account the theoretical relationships explained in the previous section, a classical mediation model is proposed in this paper, where variable transparency $(M)$ intervenes in the relationship between CSR (X) and corporate reputation (Y). Accordingly, our main hypothesis explores this relationship. Without social transparency, materialized in relevant, understandable and timely information, the relationship between CSR and reputation is not complete, since social transparency can determine the effectiveness with which CSR actions are transformed into reputation. In fact, the availability of information (it could be considered as a proxy of transparency) is recognized as a mediator in previous studies, especially in the 
relationship between organizational variables and environmental practices, focusing on the importance of providing employees with information (Sharma, 2009). In addition, Song and Lee (2015) provided empirical evidence of the mediating role of the perceptions of government transparency between the use of government social media and trust in government. In our case, companies should bear in mind that whenever the stakeholders do not receive any informative compensation, their assessment of the company will decline. Thus, corporate social transparency implies in the furnishing of information so that stakeholders can assess those issues they consider relevant to them (Kaptein, 2003, Dubbink et al., 2008) and pays off in terms of stakeholder relationships and reputation management (Dubbink et al., 2008).

Hypothesis: Transparency has a mediating effect on the relationship between CSR and corporate reputation.

In addition, the model includes several variables of control that have proved to be important in this process, as determined in previous research (Brammer \& Pavelin, 2004; Fombrun \& Shanley, 1990). Variables that have proven to be more relevant and with more theoretical support are: visibility and environmental impact of the activity, size, financial performance, and financial leverage. The relationship of variables of control with CSR, transparency and reputation in the sense theoretically expected provide consistency and validity to the model (see section 4.2).

\section{Methodological procedures}

\section{I Methodology}

In mediation models that consist of one independent variable, one mediator, and one final outcome variable, the effect of the independent variable CSR $(\mathrm{X})$ on the final outcome variable corporate reputation $(\mathrm{Y})$ can be divided into two effects: the indirect effect $a b$, which is the product of the direct effects $a$ and $b$, and the direct effect $c$ (see Figure 1). There are two types of mediation: partial mediation occurs when the direct effect $c$ is different from zero and the same sign as the mediating effect $a b$; complete mediation occurs when the direct effect $c$ is not substantial in size (Baron \& Kenny, 1986).

Figure 1 shows a path diagram for the causal relationships between the three variables CSR, transparency and corporate reputation. CSR and transparency are endogenous variables, while corporate reputation is an exogenous variable. CSR and corporate reputation are observed, while transparency is a latent variable.

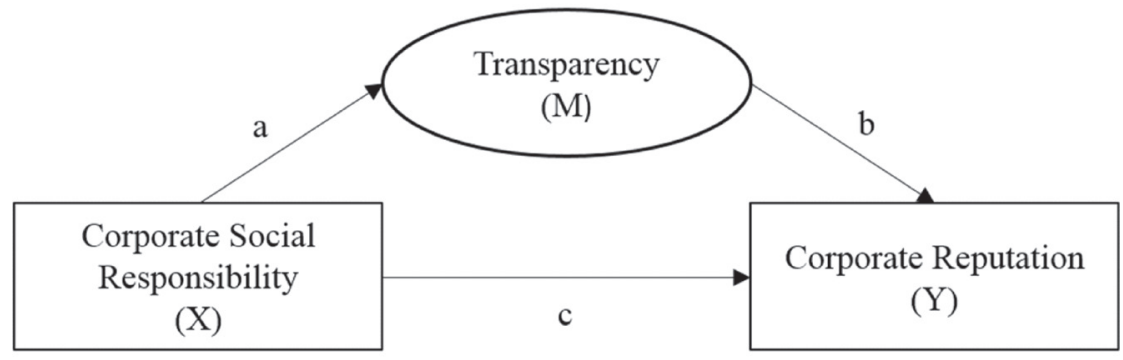

Figure 1. Pathway of a mediation process for the relationship between CSR and corporate reputation Note. Variables of control have been omitted from the figure. 
Since mediational variable is a latent variable, structural equation modeling - SEM - with the lavaan package of the software $R$ was used to test mediation and the bootstrap method to test the significance of indirect effects (Bollen \& Stine, 1990; Shrout \& Bolger, 2002), both by percentile bootstrapped confidence intervals and bias-corrected confidence intervals because the mean of the bootstrapped distribution does not exactly equal the indirect effect. A given effect is significant if the confidence interval does not contain zero.

Additionally, several fit indices were used to evaluate the adequacy of the research model. In this sense, the ratio chi-square/df is $<3$ (Ullman, 2001), the root mean square of approximation (RMSEA) is .085, the standardized root mean square residual (SRMS) is .052 and the comparative fit index (CFI) is .932 (Byrne, 1994).

To illustrate the model, we use data from the companies listed on Spanish Ibex35 from 2002 to 2015 and whose data is available in the Thomson Reuters Datastream database, a global financial and macroeconomic data platform. Companies in the sample are the most representative entities in Spain, as they have the greater market capitalization (22 companies in the sample had $82.26 \%$ of market capitalization within Ibex35 in 2015) and they represent the main sectors of the Spanish economy. The selection of a Spanish sample responds to reasons of excellence. According to KPMG (2011), one of the world's leading consultancies, Spain is within the quadrant Leading the Pack, that means that companies 'have achieved top scores in terms of professionalism of their internal systems and external accountability on the one hand and the quality of their communications on the other hand'. Thus, it is interesting to know the background of Spanish companies that achieved such a level of accountability and whether that professionalism and quality pays off. Finally, 22 companies were considered with a total of 272 observations (it is an unbalanced panel since some years have missing data for several companies).
The measurement of all the variables that appear in the model is detailed as follows.

\subsection{Variables}

Corporate Social Responsibility. To measure CSR, the variable social score was used - obtained from the Thomson Reuters Datastream database - reflecting "a company's capacity to generate trust and loyalty with its workforce, customers and society, through its use of best management practices" (Thomson Reuters, 2011).

Corporate Reputation. The measurement for corporate reputation is usually based on surveys of the company's different stakeholders. They are purely perceptual measures of multiple dimensions of social performance, such as those elaborated by Fortune or Financial Times (Fombrun, 2007). In Spain, the index Spanish Monitor of Corporate Reputation (MERCO) follows this system and has become a benchmark tool for large companies in terms of evaluation and corporate reputation management. Since 2001 , it assesses the reputation of companies operating in Spain. The development of MERCO begins with an initial provisional ranking from a survey of 15,000 Spanish managers. Subsequently, each company in that ranking is evaluated directly by diverse groups: financial analysts, NGOs, trade unions and consumer associations. The companies evaluated are ultimately given a score between 0 and 10,000 points.

\subsection{Variables of control of the model}

Visibility of the activity. The awareness or knowledge that society has of the business activity and the proximity of the company to consumers are directly related to CSR and corporate reputation (Cottrill, 1990). The higher the visibility of the activity, the higher the concern of the company to demonstrate greater social responsibility and greater transparency, which is both proactive, due to the positive influence over the volume of sales (Almazán et al., 2003) and preventative, since companies with higher visibility are more vulnerable to adverse reactions from stakeholders 
(Roberts, 1992). Proximity to the consumer is considered a proxy variable of visibility (Cottrill, 1990). This has been measured as a dichotomous variable based on the industry classification of the Madrid Stock Exchange (MSE), according to the contribution of Branco and Rodrigues (2008), in which sectors of greater visibility are given value 1 ("household goods and textiles, beverages, food and drug retailers, telecommunication services, electricity, gas distribution, water and banks"), (Branco \& Rodrigues, 2008, p. 690), and less visible sectors are given value 0 .

Environmental impact of the activity. The existence of a close relationship between certain economic activities and certain significant social or environmental externalities influences reputation and increases the pressure from different stakeholders in order to develop more active social strategies in areas related to the externalities aligned to their expectations (Brammer \& Pavelin, 2004; Branco \& Rodrigues, 2008; Clarke \& Gibson-Sweet, 1999). This pressure may modify the content of social information disclosed by the firm depending on the industrial sector to which it belongs (Clarke \& Gibson-Sweet, 1999). Environmental impact was also measured as a dichotomous variable, so that following the MSE's industry classification, the sectors whose environmental impact is higher are given a value of 1 ("mining, oil and gas, chemicals, construction and building materials, forestry and paper, steel and other metals, electricity, gas distribution and water"), (Branco \& Rodrigues, 2008, p. 691), and other sectors considered to be of lower environmental impact are given a value of 0 . This classification is consistent with that provided by Reverte (2009), based on Bowen (2000).

Size. There is substantial empirical evidence not only of its positive influence on the importance of social responsibility (Clarke \& Gibson-Sweet, 1999), but also on disclosure of information, both explained by economies of scale and greater availability of resources (Bowen, 2000; Orlitzky, 2001). Size also has a direct influence on visibility (Reverte, 2009) and reputation due to market share and power in the media (Watts \& Zimmerman, 1986). From the different proxy variables of size (turnover, total assets, number of employees...), natural logarithm of number of employees was used in this contribution, whose values were obtained from the Datastream database (variable Employees Number).

Financial performance. One of the most discussed issues within this area is the analysis of whether a CSR strategy leads to a higher financial performance (Griffin \& Mahon, 1997; Roberts, 1992; Ullmann, 1985). This position would justify CSR as a way of generating value, called business case or social impact hypothesis (Gómez, 2008). On the other hand, companies with higher financial performance have more resources to implement more social activities, which is known as the slack resources hypothesis. In the case of setting out that financial performance prior to social strategy, it is conceivable that there is a direct relationship since a higher financial performance may lead to a higher investment in social responsibility. This variable was measured by the net profit margin of each company, obtained from Datastream database (variable Net Profit Margin).

Financial leverage. This variable has been included in many investigations due to its influence on available financial resources and the cost of obtaining them, but results have been inconclusive. Some authors consider financial leverage as a restrictive element (Brammer \& Millingon, 2006), determining that firms with higher levels of debt have limited resources to invest in social actions since they must keep funds to meet their obligations to third parties. Other authors, however, consider that the dependence on external debt increases the expectations of creditors related to social activities (Almazán et al., 2003; Jensen \& Meckling, 1976; Roberts, 1992). This variable was measured by using the ratio net debt to equity also obtained from Datastream (variable Net Debt to Equity). 


\subsubsection{Mediating variable}

Transparency. The absence of a standardized measure of the company's transparency requires a system to quantify it. We consider transparency beyond disclosure, so we have tried to make implicit the concepts of relevance, understandability and timeliness by measuring transparency as a latent variable inferred from the following variables obtained from the Thomson Reuters Datastream database. Relevance, understandability and timeliness of information are implicit when the company explains the engagement with its stakeholders, and also publishes a separate report with ESG information (in accordance with GRI guidelines and external audit) or includes a section on ESG information in the annual report, a timely publication.

a) GRI Report. The score from 0 to 100 shows how the company's performance compares to the entire ASSET4 universe based on the question Is the company's CSR report published in accordance to the GRI guidelines?

b) Transparency. The score from 0 to 100 shows how the company's performance compares to the entire ASSET4 universe based on the question Does the company publish a separate CSR/H\&S/Sustainability report or publish a section in its annual report on CSR/H\&S/Sustainability?

c) Stakeholder engagement. The score from 0 to 100 shows how the company's performance compares to the entire ASSET4 universe based on the question Does the company explain how it engages with its stakeholders?

d) CSR reporting auditor. The score from 0 to 100 shows how the company's performance compares to the entire ASSET4 universe based on the question Does the company have an external auditor for its CSR/H\&S/Sustainability Report?

\section{Results presentation and analysis}

Descriptive statistics and correlation analysis of the variables in the model are presented in table 1. It is observed that companies in the sample are reputed companies (average of 5,559 in the MERCO ranking) and they are quite committed to CSR (average of 89,72).

Table 1

Descriptive statistics and correlation analysis

\begin{tabular}{|c|c|c|c|c|c|c|c|c|c|}
\hline Variables & 1 & 2 & 3 & 4 & 5 & 6 & Min. & Max. & Mean \\
\hline $\begin{array}{l}1 \text { Corporate } \\
\text { Reputation }\end{array}$ & & & & & & & 0.00 & $10,000.0$ & $5,559.30$ \\
\hline 2 CSR actions & $0.289^{* * *}$ & & & & & & 17.55 & 99.00 & 89.72 \\
\hline 3 Visibility & $0.220^{* * *}$ & 0.000 & & & & & 0.00 & 1.00 & 0.80 \\
\hline $\begin{array}{l}4 \text { Environmental } \\
\text { impact }\end{array}$ & $-0.278^{* * *}$ & 0.062 & $-0.476^{* * *}$ & & & & 0.00 & 1.00 & 0.52 \\
\hline 5 Size & $0.680^{* * *}$ & $0.23^{* * *}$ & $-0.173^{* * *}$ & $-0.175^{* * *}$ & & & 6.78 & 12.58 & 9.90 \\
\hline $\begin{array}{l}6 \text { Financial } \\
\text { performance }\end{array}$ & $-0.149^{* *}$ & -0.098 & $0.258^{* * *}$ & 0.041 & $-0.291^{* * *}$ & & -39.04 & 43.45 & 11.53 \\
\hline 7 Leverage & -0.098 & 0.110 & $-0.103^{*}$ & -0.082 & 0.100 & $0.117^{*}$ & 0.00 & 14.11 & 2.23 \\
\hline
\end{tabular}

The measures of absolute fit of the model estimated present values within the recommended limits. The root mean square error of approximation (RMSEA) ranges from 0 to 1 and smaller is better. In our case, RMSEA is 0.085 (around 0.08). For this reason, the hypothesis of adequacy between the proposed model and the data used is supported. Moreover, the results obtained from the incremental fit measurements are also acceptable since the value 
of the comparative fit index (CFI) is 0.932 (higher than 0.90).

Results support the assumption that the relationship between CSR actions and corporate reputation is mediated by transparency, confirming the main hypothesis. Both direct effects $a$ and $b$ that constitute the indirect effect were significant (see Table 2) and direct effect $c$ was not substantial in size, so a complete mediation is suggested. To test the significance of the mediation effect, Sobel test was performed $\left(2.95^{* * *}\right)$. It proves that the reduction in the effect of the independent variable (corporate reputation), after including the mediator (transparency) is a significant reduction, so the mediation effect is statistically significant. One alternative to Sobel test is bootstrapping. Thus, bootstrap analyses were conducted to estimate the confidence intervals of the direct effects and the indirect effects based on 1,000 bootstrap samples. Both the percentile and the bias-corrected bootstrapped confidence intervals revealed a significant indirect effect $a b$ (see Table 2 ), so transparency is a statistically significant mediator.

Table 2

\section{Results of mediating model}

\begin{tabular}{|c|c|c|c|c|c|c|c|c|}
\hline \multirow{3}{*}{$\begin{array}{l}\text { Estimator } \\
\mathrm{X} \rightarrow \mathrm{M}:=\mathrm{a}\end{array}$} & \multicolumn{3}{|c|}{ Z-statistic } & \multicolumn{5}{|c|}{ Bootstrapping (1000 samples) } \\
\hline & \multirow{2}{*}{$\begin{array}{c}\text { Estimate } \\
0.667\end{array}$} & \multirow{2}{*}{$\begin{array}{c}\text { SE } \\
0.089\end{array}$} & \multirow{2}{*}{$\frac{\mathbf{Z}}{9.400^{* * *}}$} & \multirow{2}{*}{$\begin{array}{c}\text { SE } \\
0.089\end{array}$} & \multicolumn{2}{|c|}{$95 \% \mathrm{CI}$} & \multicolumn{2}{|c|}{$95 \%$ CI BC } \\
\hline & & & & & 0.690 & 1.047 & 0.707 & 1.079 \\
\hline $\mathrm{M} \rightarrow \mathrm{Y}:=\mathrm{b}$ & 0.296 & 11.961 & $3.231^{* * *}$ & 12.405 & 18.954 & 69.213 & 19.384 & 70.311 \\
\hline $\mathrm{X} \rightarrow \mathrm{Y}:=\mathrm{c}$ & -0.081 & 10.587 & -1.248 & 10.169 & -35.726 & 5.226 & -34.812 & 5.543 \\
\hline $\mathrm{X} \rightarrow \mathrm{M} \rightarrow \mathrm{Y}:=\mathrm{ab}$ & 0.198 & 9.835 & $3.290^{* * *}$ & 10.171 & 15.761 & 57.509 & 15.825 & 57.580 \\
\hline
\end{tabular}

Note. Estimates are standardized. $\mathrm{X}=\mathrm{CSR} ; \mathrm{M}=$ Transparency; $\mathrm{Y}=$ Corporate Reputation; SE = Standard Error; CI = Confidence Interval; $\mathrm{BC}=$ Bias-corrected.

In relation to the control hypotheses (see Table 3), results show that only the one related to visibility is proven, since a significant and direct relationship was found between the visibility of the activity and CSR, transparency and corporate reputation. Regarding CSR actions, all variables of control are statistically significant, and relationships are those expected, except for the relationship concerning financial performance, which is indirect. Regarding transparency, only CSR and visibility seem to have an effect on the independent variable. Finally, with respect to corporate reputation, we can see that including the mediating effect, the relationship with CSR changes direction. Transparency, size and financial leverage are significant variables and relationships are those expected.

Table 3

Results of estimation model

\begin{tabular}{lcccc}
\hline \multirow{2}{*}{ Hypotheses } & Dependent Variable & \multicolumn{3}{c}{ Independent Variable } \\
\cline { 3 - 5 } & & CSR & Transparency & Corporate reputation \\
\hline MH & Transparency & - & $0.667^{* * *}(\mathrm{a})$ & $-0.081(\mathrm{c})$ \\
$\mathrm{HC1}$ & Visibility & - & - & $0.296^{* * *}(\mathrm{~b})$ \\
$\mathrm{HC} 2$ & Environmental impact & $0.227^{* * *}$ & $0.145^{*}$ & $0.306^{* * *}$ \\
$\mathrm{HC} 3$ & Size & $0.255^{* * *}$ & 0.087 & -0.012 \\
$\mathrm{HC} 4$ & FP & $-0.118^{* * *}$ & 0.033 & $0.727^{* * *}$ \\
HC5 & Leverage & $0.132^{* *}$ & 0.040 & -0.021 \\
\hline
\end{tabular}

Note. Estimates are standardized 


\section{Conclusion}

The relationship between CSR and reputation has been studied in literature, but with mediation analysis, we acquire a more meaningful understanding concerning the mechanisms of implementation of CSR actions and the creation of corporate reputation. Our intention was to shed light on transparency, considered as a step beyond disclosure, and whether it plays a role in that relationship through a structural equation model in a sample of 22 Spanish listed companies for the period 2002-2015.

In a pragmatic sense, the reasons behind implementing CSR actions might be diverse. There are companies or managers that may use (or abuse) CSR actions as an item of a to do list in order not to stay behind competitors, and there are other really committed companies that consider CSR as an intrinsic value that does not need to be disclosed (they are responsible because they believe they must be responsible, not because others require it). But the truth is that companies need to communicate their CSR actions to attain reputation, but they must do it properly, in a transparent manner (reliably, understandably, timely). Only in that way stakeholders will trust and rely on CSR (MacLean \& Rebernak, 2007; Swift, 2001) increasing their positive assessments and, therefore, increasing corporate reputation. According to the stakeholder theory, which integrates issues of the legitimacy theory and the agency theory (Garriga \& Melé, 2004), CSR communication is considered a method of obtaining legitimacy from stakeholders, as well as a way to satisfy interests of a heterogeneous group of stakeholders that influence its survival (Odriozola \& Baraibar-Diez, 2017). Thus, the stakeholder theory is a valid framework to analyze the mediating effect of transparency in the relationship between CSR and corporate reputation.

Corporate transparency stems from disclosure of information and aims to provide stakeholders with accurate information to make rational decisions concerning their contractual relationship with the firm, reducing uncertainty, improving efficiency and contributing to the sustainable development of the company. However, the implementation of transparency is more homogeneous when information is financial and very heterogeneous on ESG issues. The difference is mainly due to the type of information disclosed, standardized and regulated in the financial case and less standardized in the social case.

Thus, the negative impact of information asymmetry in the efficiency of transactions, the enlargement of the number of stakeholders in a global economy and the uncertainty generated in consumers and investors due to poor information of corporate actions have identified transparency as one of the cornerstones for the development of an economic activity, and one of the main challenge for practitioners. Therefore, corporate social transparency is a relevant field of study both in its definition and implementation in the company and in the analysis of its effects.

There is still an existing problem when identifying transparency with disclosure. We understand transparency as something beyond disclosure, and we have tried to reflect that in our proposed measurement of transparency, inferred by some observed variables such as stakeholder engagement, CSR reporting auditor or GRI reporting, that implicitly include the concepts of relevance, understandability and timeliness of information. This contribution has taken a step forward in the conception of transparency, making stricter the requirements of disclosure. The empirical results show that transparency is a mediator in the relationship between CSR and corporate reputation. Thus, disclosing standardized and audited CSR information, explaining how the company is engaged to its stakeholders, is one of the clearest management options to enhance the effectiveness of CSR actions.

Regarding variables of control, we have had interesting results too. Visibility is the variable with a statistically expressive relationship with 
CSR, transparency and corporate reputation, revealing that firms that are more visible tend to implement more CSR actions, be more transparent and have better reputation. Environmental impact has a direct relationship with the importance that the company attaches to social actions and transparency, and an inverse relationship with corporate reputation. Companies with a higher environmental impact try to compensate this negative effect by disclosing information that is more transparent. Size and leverage are significantly related to CSR and corporate reputation, but not with transparency. It may indicate that the way information is disclosed has nothing to do with the size or resources of the issuer company.

The main limitations of this study derive from the scope of analysis, as only 22 companies compose the sample (representing more than $80 \%$ of market capitalization). Despite the fact that Spanish companies proved to be excellent in accountability and represent an interesting focus of analysis, the truth is that a larger sample should be used to extrapolate results. Ultimately, this paper highlights the importance of transparency beyond disclosure since information must meet certain criteria such as relevance, understandability and timeliness of information. The real and clear implication of these criteria in performance of companies as well as the difficulty of measuring them requires that future development of research contribute to that challenge, developing multidisciplinary approaches in the field of transparency that allow to improve information intricacies and the most efficient way to reach stakeholders.

\section{References}

Aggarwal, R., \& Kyaw, N. (2009). International variations in transparency and capital structure: Evidence from European Firms. Journal of International Financial Management and Accounting, 20(1), 1-34.

Aksu, M., \& Kosedag, A. (2006). Transparency and disclosure scores and their determinants in the
Istanbul Stock Exchange. Corporate Governance: An International Review, 14(4), 277-296.

Almazán, A., Suárez, J., \& Titman, S. (2003). Stakeholder, transparency and capital structure [Working Paper No. w10101]. National Bureau of Economic Research, Massachusetts, MA.

Arikan, E., Kantur, D., Maden, C., \& Telci, E. E. (2016). Investigating the mediating role of corporate reputation on the relationship between corporate social responsibility and multiple stakeholder outcomes. Quality \& Quantity, 5O(1), 129-149.

Armstrong, E. (2005). Integrity, Transparency and Accountability in Public Administration: Recent trends, regional and international developments and emerging issues. New York: UNDESA.

Baraibar-Diez, E., \& Luna-Sotorrio, L. (2012). Transparencia social e hipótesis del impacto social: Análisis en el IBEX35. Universia Business Review, 36, 108-123.

Baraibar-Diez, E., Odriozola, M. D., \& Fernández, J. L. (2017). A survey of transparency: An intrinsic aspect of business strategy. Business Strategy and the Environment, 26(4), 480-489.

Baron, R. M., \& Kenny, D. A. (1986). The moderator-mediator variable distinction in social psychological research: Conceptual, strategic and statistical considerations. Journal of Personality and Social Psychology, 51(6), 1173-1182.

Blanco, B., Guillamón-Saorín, E., \& Guiral, A. (2013). Do non-socially responsible companies achieve legitimacy through social responsible actions? The Mediating Effect of Innovation. Journal of Business Ethics, 117(1), 67-83

Bollen, K. A., \& Stine, R. (1990). Direct and indirect effects: Classical and bootstrap estimates of variability. Sociological Methodology, 20, 115-140

Botosan, C. (1997). Disclosure level and the cost of equity capital. The Accounting Review, 72(3), 323-349. 
Bowen, F. (2000). Environmental visibility: A trigger of green organizational response? Business Strategy and the Environment, 9(2), 92-107.

Brammer, S., \& Millington, A. (2006). Firm size, organizational visibility and corporate philanthropy: An empirical analysis. Business Ethics: A European Review, 15(1), 6-18.

Brammer, S., \& Pavelin, S. (2004). Building a good reputation. European Management Journal, 22(6), 704-713.

Brammer, S., \& Pavelin, S. (2006). Corporate reputation and social performance: The importance of fit. Journal of Management Studies, 43(3), 435-455.

Brammer, S., \& Pavelin, S. (2016). Corporate social responsibility and corporate reputation. In G. Aras (2016), A handbook of corporate governance and social responsibility (pp. 153-169). Massachusetts: CSR Press.

Branco, M., \& Rodrigues, L. (2008). Factors influencing social responsibility disclosure by Portuguese Companies. Journal of Business Ethics, 83(4), 685-701.

Bushman, R., Piotroski, J., \& Smith, A. (2004). What determines corporate transparency? Journal of Accounting Research, 42(2), 207.

Byrne, B. M. (1994). Structural equation modeling with EQS and EQS/Windows. Thousand Oaks, CA: Sage Publications.

Campbell, D., Craven, B., \& Shrives, P. (2003). Voluntary social reporting in three FTSE sectors: A comment on perception and legitimacy. Accounting, Auditing and Accountability Journal, 16(4), 558-581.

Clarke, J., \& Gibson-Sweet, M. (1999). The use of corporate social disclosures in the management of reputation and legitimacy: A cross-sectoral analysis of UK Top 100 Companies. Business Ethics: A European Review, 8(1), 5-13.
Cochran, P. L., \& Wood, R. A. (1984). Corporate social responsibility and financial performance. Academy of Management Journal, 27(1), 42-56.

Cottrill, M. (1990). Corporate social responsibility and the Marketplace. Journal of Business Ethics, 9(9), 723-729.

Dahlsrud, A. (2008). How corporate social responsibility is defined: An analysis of 37 definitions. Corporate Social Responsibility and Environmental Management, 15(1), 1-13.

De la Fuente, J. M., \& de Quevedo Puente, E. (2003). Empirical analysis of the relationship between corporate reputation and financial performance: A survey of the literature. Corporate Reputation Review, 6(2), 161-177.

De Quevedo-Puente, E., de la Fuente, J. M., \& Delgado, J. B. (2005). Reputación corporativa y creación de valor: Marco teórico de una relación circular. Investigaciones Europeas de Dirección y Economia de la Empresa, 11(2), 81-97.

Devine, I., \& Halpern, P. (2001). Implicit claims: The role of corporate reputation in value creation. Corporate Reputation Review, 4(1), 42-49.

Dierkes, M., \& Antal, A. B. (1985). The usefulness and use of social reporting information. Accounting, Organizations and Society, 1O(1), 29-34.

Dubbink, W., Graafland, J., \& van Liedekerke, L. (2008). CSR, Transparency and the role of intermediate organisations. Journal of Business Ethics, 82(2), 391-406.

Eberle, D., Berens, G. \& Li, T. (2013). The impact of interactive corporate social responsibility communication on corporate reputation. Journal of Business Ethics, 118(4), 731-746.

Ewer, S. (2007). Transparency and understandability, but for whom? The CPA Journal, 77(2), 16. 
Falkenberg, J., \& Brunsael, P. (2011). Corporate social responsibility: A strategic advantage or a strategic necessity? Journal of Business Ethics, 99(1), 9-16.

Fernández Sánchez, J. L., Luna Sotorrio, L., \& Baraibar Diez, E. (2015). The relationship between corporate social responsibility and corporate reputation in a turbulent environment: Spanish evidence of the Ibex35 firms. Corporate Governance - The International Journal of Business in Society, 15(4), 563-575.

Finel, B., \& Lord, K. (1999). The surprising logic of transparency. International Studies Quarterly, 43(2), 315-339.

Fombrun, C. (2007). List of Lists: A compilation of international corporate reputation ratings. Corporate Reputation Review, 10(2), 144-153.

Fombrun, C., \& Shanley, M. (1990). What's in a Name? Reputation building and corporate strategy. Academy of Management Journal, 33(2), 233.

Frazier, P. A, Tix, A. P., \& Barron, K. E. (2004). Testing moderator and mediator effects in counseling psychology research. Journal of Counseling Psychology, 51(1), 115-134.

Friedman, M. (1970, September 13). The social responsibility of business is to increase its profits. New York Times Magazine. 122-124.

Fuente, J. A., García-Sánchez, I. M., \& Lozano, M. B. (2017). The role of the board of directors in the adoption of GRI guidelines for the disclosure of CSR information. Journal of Cleaner Production, 141, 737-750.

Fung, A., Weil, D., Graham, M., \& Fagotto, E. (2004). The political economy of transparency: What makes disclosure policies effective? [OP03-04]. Ash Institute for Democratic Governance and Innovation, John F. Kennedy School of Government, Harvard University, Cambridge,
MA, United States. Retrieved from http://ssrn. com/abstract $=766287$

García-Meca, E., \& Martínez, I. (2005). Assessing the quality of disclosure on intangibles in the Spanish capital market. European Business Review, 17(4), 305-313.

Garriga, E., \& Melé, D. (2004). Corporate social responsibility theories: Mapping the territory. Journal of Business Ethics, 53(1), 51-71.

George, G., Dahlander, L., Graffin, S. D., \& Sim, S. (2016). Reputation and status: Expanding the role of social evaluations in management research. Academy of Management Journal, 59(1), 1-13.

Gómez, F. (2008). Responsabilidad social corporativa y performance financiero: Treinta y cinco ańos de investigación empírica en busca de un consenso. Principios: Estudios de Economía Politica, 11, 5-24.

Gray, S. (1988). Towards a theory of cultural influence on the development of Accounting Systems Internationally. Abacus, 24(1), 1-15.

Griffin, J., \& Mahon, J. (1997). The Corporate social performance and corporate financial performance debate. Business and Society, 36(1), 5-31.

Hogarth, K., Hutchinson, M., \& Scaife, W. (2016). Corporate philanthropy, reputation risk management and shareholder value: A Study of Australian corporate giving. Journal of Business Ethics. doi:10.1007/s10551-016-3205-8

Holt, T. P., \& DeZoort, T. (2009). The effects of internal audit report disclosure on investor confidence and investment decisions. International Journal of Auditing, 13(1), 61-77.

Hooghiemstra, R. (2000). Corporate communication and impression management: New perspectives why companies engage in corporate social reporting. Journal of Business Ethics, 27(1-2), 55-68. 
Hosmer, L. T. (1995). Trust: The connecting link between organizational theory and philosophical ethics. Academy of Management Review, 20(2), 379-403.

Huang, C., \& Lien, H. (2012). An empirical analysis of the influences of corporate social responsibility on organizational performance of Taiwan's construction industry: Using corporate image as a mediator. Construction Management and Economics, 30(4), 263-275.

Ihlen, Ø., Bartlett J. L., \& May, S. (2011). Corporate Social Responsibility and Communication. In $\varnothing$. Ihlen, J. L. Bartlett, S. May (Eds), The handbook of communication and corporate social responsibility (pp. 3-22), New York, NY: Wiley-Blackwell.

Jensen, M., \& Meckling, W. (1976). Theory of the Firm: Managerial behavior, agency costs and ownership structure. Journal of Financial Economics, 3(4), 305-360.

Jensen, M., Marshall, B., \& Pugh, W. (2006). Does quantity reflect quality? Financial disclosure size and future performance. Managerial Finance, 32(1), 39-50.

Kaptein, M., \& Van Tulder, R. (2003). Toward effective stakeholder dialogue. Business and Society Review, 108(2), 203-225.

Kim, J. (2015). The Effect of corporate social responsibility benefits on corporate reputation and repurchase intention: Focused on the discount stores. Korea Logistics Review, 25(4), 121-133.

KPMG. (2011). KPMG International Survey of Corporate Responsibility Reporting 2011. Amsterdam: KPMG International Global Sustainability Services. Retrieved from http:// www.econsense.de/sites/all/files/Surveycorporate-responsibility-reporting-2011.pdf

Lai, C.-S., Chiu, C.-J., Yang, C.-F., \& Pai, D.-C. (2010). The effects of corporate social responsibility on brand performance: The mediating effect of industrial brand equity and corporate reputation. Journal of Business Ethics, 95(3), 457-469.

Lee, C., Chang, D., Kim, N., \& Lee, H. (2016). A study on the interaction between corporate reputation and negativity framing on consumer evaluation of corporate social responsibility. Asian Marketing Journal, 17(4), 105-203.

Luna, L., \& Baraibar-Diez, E. (2011). Análisis sectorial del efecto de las acciones de responsabilidad social corporativa en la reputación. Revista Europea de Dirección y Economía de la Empresa, 20(4), 177-196.

MacLean, R., \& Rebernak, K. (2007). Closing the credibility gap: The challenges of corporate responsibility reporting. Environmental Quality Management, 16(4), 1-6.

Melo, T., \& Garrido-Morgado, A. (2012). Corporate reputation: A combination of social responsibility and industry. Corporate Social Responsibility and Environmental Management, 19(1), 11-31.

Mitchell, R. K., Agle, B. R., Wood, D. J. (1997). Toward a theory of stakeholder identification and salience: Defining the principle of who and what really counts. Academy of Management Review 22(4), 853-886.

Odriozola, M. D., \& Baraibar-Diez, E. (2017). Is corporate reputation associated with quality of CSR reporting? Evidence from Spain. Corporate Social Responsibility and Environmental Management, 24(2), 121-132.

Odriozola, M. D., Martín, A., \& Luna, L. (2015). The relationship between labour social responsibility practices and reputation. International Journal of Manpower, 36(2), 236-251.

Olmedo, I., Martínez, I. M., Arcas, N., \& Longuinos, J. (2012). Relación circular entre 
ética, responsabilidad social y reputación de las cooperativas. REVESCO: Revista de Estudios Cooperativos, 107, 129-154.

Orlitzky, M. (2001). Does firm size confound the relationship between corporate social performance and firm financial performance? Journal of Business Ethics, 33(2), 167-180.

Ortiz Martínez, E., \& Crowther, D. (2008). Is disclosure the right way to comply with stakeholders? The Shell case. Business Ethics: A European Review, 17(1), 13-22.

Penno, M. C. (1997). Information quality and voluntary disclosure. The Accounting Review 72(2), 275-284.

Pérez, A., López, C., \& García-De los Salmones, M. M. (2017). An empirical exploration of the link between reporting to stakeholders and corporate social responsibility reputation in the Spanish context. Accounting, Auditing \& Accountability Journal, 30(3), 668-698.

Piechocki, R. (2004). Transparency of annual sustainability reports. Corporate Reputation Review, 7(2), 107-123.

Prado-Lorenzo, J., Garcia-Sanchez, I. M., \& Gallego-Álvarez, I. (2012). Effects of activist shareholding on corporate social responsibility reporting practices: An empirical study in Spain. Journal of Economics, Finance and Administrative Science, 17(32), 7-16.

Reverte, C. (2009). Determinants of corporate social responsibility disclosure ratings by Spanish Listed Firms. Journal of Business Ethics, 88(2), 351-366

Roberts, R. W. (1992). Determinants of corporate social responsibility disclosure: An application of stakeholder theory. Accounting, Organizations and Society, 17(6), 595-612.

Saeidi, S. P., Sofian, S., Saeidi, P., Saeidi, S. P., \& Saeidi, S. A. (2015). How does corporate social responsibility contribute to firm financial performance? The mediating role of competitive advantage, reputation, and customer satisfaction. Journal of Business Research, 68(2), 341-350.

Schnietz, K., \& Epstein, M. (2005). Exploring the financial value of a reputation for corporate social responsibility during a crisis. Corporate Reputation Review, 7(4), 327-345.

Sharma, S. (2009). The Mediating effect of information availability between organization design variables and environmental practices in the Canadian Hotel Industry. Business Strategy and the Environment, 18(4), 266-276.

Shrout, P. E., \& Bolger, N. (2002). Mediation in experimental and nonexperimental studies: New procedures and recommendations. Psychological Methods, 7(4), 422-445.

Skard, S., \& Thorbjornsen, H. (2014). Is Publicity always better than advertising? The role of brand reputation in communicating corporate social responsibility. Journal of Business Ethics, 124(1), 149-160.

Song, C., \& Lee, J. (2015). Citizen's use of social media in government, perceived transparency, and trust in government. Public Performance \& Management Review, 39(2), 430-453.

Story, J., \& Neves, P. (2014). When corporate social responsibility (CSR) increases performance: Exploring the role of intrinsic and extrinsic CSR attribution. Business Ethics: A European Review, 14(2), 111-124.

Surroca, J., Tribo, J. A., \& Waddock, S. (2010). Corporate responsibility and financial performance: The role of intangible resources. Strategic Management Journal, 31(5), 463-490.

Swift, T. (2001). Trust, reputation and corporate accountability to stakeholders. Business Ethics: $A$ European Review, 10(1), 16-26.

Toms, J. S. (2002). Firms resources, quality signals and the determinants of corporate environmental reputation: Some UK Evidence. The British Accounting Review, 34(3), 257-282. 
Ullmann, A. A. (1985). Data in search of a theory: A Critical examination of the relationships among social performance, social disclosure, and economic performance of U.S. Firms. Academy of Management Review, 10(3), 540-557.

Ullman, J. B. (2001). Structural equation modeling. In B. G. Tabachnick \& L. S. Fidell (2001). Using Multivariate Statistics (4th ed., pp. 653- 771). Needham Heights, MA: Allyn \& Bacon.

Vogelgesang, G. R., Leroy, H., \& Avolio B. J. (2013). The mediating effects of leader integrity with transparency in communication and work engagement/performance. The Leadership Quarterly, 24(3), 405-413.

Walker, K. (2010). A Systematic review of the corporate reputation literature: Definition, measurement, and theory. Corporate Reputation Review, 12(4), 357-387.

Watts, R. L., \& Zimmerman, J. L. (1986). Positive accounting theory. New Jersey: Prentice Hall.

Wilson, T., \& Walsh, C. (1996). Information behaviour: An interdisciplinary perspective. United Kingdom: The British Library Board.

Zavyalova, A., Pfarrer, M. D., Reger, R. K., \& Hubbard, T. D. (2016). Reputation as a benefit and a burden? How stakeholders' organizational identification affects the role of reputation following a negative event. Academy of Management Journal, 59(1), 253-276.

\section{About the authors:}

1. Elisa Baraibar-Diez, PhD in Management, University of Cantabria, Santander, Spain. E-mail: Elisa. baraibar@unican.es

ORCID

(iD_0000-0003-4677-3255

2. Ladislao Luna Sotorrío, PhD in Economic and Management Sciences, University of Cantabria, Santander, Spain. E-mail: lunal@unican.es

ORCIID

(D_0000-0002-3504-6485

\section{Contribution of each author:}

\begin{tabular}{lcc}
\hline Contribution & Elisa Baraibar-Diez & Ladislao Luna Sotorrío \\
\hline 1. Definition of research problem & $\sqrt{ }$ & $\sqrt{ }$ \\
2. Development of hypotheses or research questions (empirical studies) & $\sqrt{ }$ \\
3. Development of theoretical propositions (theoretical Work) & $\sqrt{ }$ \\
4. Theoretical foundation/ Literature review & $\sqrt{ }$ \\
5. Definition of methodological procedures & $\sqrt{ }$ \\
6. Data collection & $\sqrt{ }$ \\
7. Statistical analysis & $\sqrt{ }$ \\
8. Analysis and interpretation of data & $\sqrt{ }$ \\
9. Critical revision of the manuscript & $\sqrt{ }$ \\
10. Manuscript Writing & $\sqrt{ }$ \\
11. Other (supervision) & \\
\hline
\end{tabular}

